\title{
Universiteit
}

Leiden

The Netherlands

\section{The future of International Law : A Human Rights perspective with some comments on the Leiden School of International Law}

Dugard, C.J.R.

\section{Citation}

Dugard, C. J. R. (2007). The future of International Law : A Human Rights perspective with some comments on the Leiden School of International Law. In . Leiden. Retrieved from https://hdl.handle.net/1887/12401

Version:

Not Applicable (or Unknown)

License:

Leiden University Non-exclusive license

Downloaded from: $\quad$ https://hdl.handle.net/1887/12401

Note: To cite this publication please use the final published version (if applicable). 
Prof.dr. C.J.R. Dugard

The future of International Law:

A Human Rights perspective 



\title{
The future of International Law: A Human Rights perspective with some comments on the Leiden School of International Law
}

\author{
rede uitgesproken door \\ Prof.dr. C.J.R. Dugard \\ ter gelegenheid van zijn afscheid als hoogleraar \\ Internationaal Publiekrecht \\ aan de Universiteit Leiden \\ op vrijdag 20 april 2007

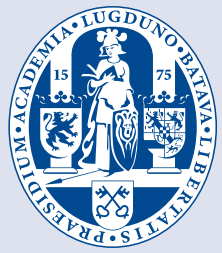 \\ Universiteit Leiden
}


A valedictory lecture is intended to be a farewell to a particular phase of one's life. Today I bring to an end the chapter of my life at Leiden. There have been two major chapters in my life: one long and the other relatively short. The first chapter, which lasted for sixty years, was my life in South Africa. This chapter was about growing up in a strange society; about trying to promote human rights in a racist and oppressive society; and about participating in the changes that took place in the 1990's. This is a chapter that I aim to write about when I retire from a more active life! The second chapter, about which I shall speak today, started in 1998 when I was appointed Professor of International Law at the University of Leiden. It is a rich chapter, both in terms of changes to my personal life and in terms of professional experience. Professionally, my Leiden chapter has been dominated by three things. First, my work at the university - particularly teaching in its challenging advanced LLM program; secondly, my work at the International Law Commission, where I served as Special Rapporteur on Diplomatic Protection from 1999 to 2006; and, thirdly, my experience as Special Rapporteur to the Commission on Human Rights (and later the Human Rights Council) on human rights in the Occupied Palestinian Territory.

In my talk today I shall address the future of international law, with particular reference to human rights. I am fearful of the future of human rights in today's world. A whole range of factors place the international protection of human rights in danger. Today I shall talk about two of these factors which fall within my own experience. I shall approach the subject from the perspectives of the International Law Commission and Human Rights Council. First, I shall consider the implications of the different approaches to international law taken by academic lawyers and government lawyers for the future of human rights. Secondly, I shall consider the implications of divisions in the Human Rights Council over the Occupied Palestinian Territory for the future of human rights. After this I shall make some remarks about the role of the International Court of Justice in resolving these differences. I shall conclude with some comments about international law at Leiden.

\section{Academic and Government International Lawyers: Different Perspectives in Relation to Matters Concerning Human Rights}

It is trite that the content of international law has changed dramatically in the past fifty years, largely as a result of the adoption of multilateral treaties dealing with a wide range of subjects, including human rights, trade, the environment, international crime and disarmament. But more dramatic, perhaps, has been the change in relation to thinking about the nature of international law, encapsulated in the notions of jus cogens and obligations erga omnes.

Traditionally international law was seen as a system of neutral rules, equal in status ${ }^{1}$, to which states had consented, ${ }^{2}$ expressly by treaty or impliedly by "constant and uniform usage". ${ }^{3}$ A state retained exclusive jurisdiction over persons and events within its own territory, with the result that its treatment of its own nationals could not be seen as being of international concern. A state might protect its own nationals abroad, if it so wished, but the fate of foreign nationals abroad, although a cause for political concern, was not a matter of legal concern ${ }^{4}$ - as illustrated by the 1966 Judgment of the International Court of Justice in the South West Africa Cases. ${ }^{5}$ Finally, although certain conduct attracted individual criminal responsibility, the absence of a permanent international criminal court ensured impunity. 
All this was changed. The sources of international law are no longer predicated on consent, and have been expanded to include General Assembly resolutions, the products of the International Law Commission, general principles (particularly in the field of human rights and humanitarian law) and "soft law" contained in the declarations of international conferences. Some rules of international law, particularly those governing the use of force and human rights, are characterized as peremptory norms or norms of jus cogens and are viewed as being of a higher status than other rules. Domestic jurisdiction is no longer exclusive where human rights are concerned as a result of human rights conventions and the practice of the United Nations. A distinction is drawn between obligations that involve only the parties to a dispute and obligations that concern all states - obligations erga omnes. All states have an interest in enforcement of such obligations. Consequently, states now have legal standing to protect non-nationals in international litigation - according to the International Law Commission's Draft Articles on State Responsibility ${ }^{6}$ and a separate opinion of Judge Simma in the case of DRC $\mathrm{v}$ Uganda. Finally there is now a permanent international criminal court, in addition to several ad hoc tribunals, which ensures that there is no impunity for international crimes.

We academic lawyers are understandably excited by these changes and do our best to expand and extend them. All sorts of customary and treaty norms are claimed to be jus cogens and to create obligations erga omnes; non-law becomes soft law and soft law becomes hard law. ${ }^{8}$ As academic international lawyers outnumber international law practitioners, unlike the situation with any branch of national law, the opinions of academic lawyers become the law - at least as far as many academic lawyers are concerned. We have the gospels according to the
American Journal of International Law, the British Year Book of International Law, the Annuaire Français and the Zeitschrift für Ausländisches Öffentliches Recht und Völkerrecht. State practice is overlooked in our enthusiasm to create a brave new world, premised on the principles of the new international law. A world in which state sovereignty is no longer a factor, a world in which the community of personkind is governed by the Rule of Law, a world in which peace and human rights are secure and in which the energy of personkind is addressed towards resolving poverty and inequality.

I may have painted an exaggerated picture of the academic perception of international law. But I fear that it is not too far off the mark. And here I speak as an academic lawyer who had virtually no contact with government or government lawyers until after the fall of apartheid in 1994 and, more accurately, until my election to the International Law Commission in 1997. I believed in the gospel of the law journals until I was brought down to earth by the experience of the International Law Commission. Over the years the International Law Commission has changed from a body of serious academics meeting on summer vacation in Geneva to a body of law advisers, ambassadors, government ministers and academics. The new international law vies with the old for acceptance in the process of codification, state practice receives more attention than jus cogens and erga omnes and there is considerable skepticism about the attention paid to human rights in the international legal order. This was brought home to me sharply when as Special Rapporteur on diplomatic protection I attempted to portray diplomatic protection as a means of protecting human rights rather than the interests of the state. A proposal that sought to compel states to exercise diplomatic protection on behalf of a national whose human rights had been violated by 
the breach of a norm of jus cogens was unsuccessful, as were other proposals that aimed to inject human rights norms into diplomatic protection. Colleagues made it clear that human rights, jus cogens and erga omnes were to be treated with great caution in the codification process. State interests also feature prominently in the legislative process, albeit in disguise - and invariably such interests are clothed in the language of traditional international law. For instance, I was surprised by objections raised by the United States to several of the draft articles on diplomatic protection. Despite the fact that the provisions were supported by constant and uniform United States practice, the United States argued that they did not enjoy sufficient support in state practice to constitute customary law. Amazed, I approached a friend in the State Department, who explained that the previous US practice had been shaped by the fact that until recently the US saw itself as a plaintiff state. Now that it had become a respondent state in international litigation it could no longer accept such rules. Hence the argument that they were unsupported by state practice.

New international law does, at least, receive a fair hearing in the International law Commission. This is less the case in the Sixth Committee - the legal committee of the General Assembly. While in the Commission on Human Rights - now the Human Rights Council - which I have experienced since 2001 - the "old" law prevails.

The harsh reality is that the battle for the new international law is far from won, particularly in the field of human rights.

Respect for the domestic jurisdiction of states still features prominently in the practice of states and regional arrangements in Africa and Asia, despite the fact that appeals to the protection of Article 2 ( 7 ) of the UN Charter are rare.
Unfortunately this is too little appreciated by Europeans who often see the world through the spectacles of their own achievements in the internationalization of human rights. Consent is still the basis of international law and soft law remains non-law. Jus cogens and erga omnes are seen as foreign maxims of no practical significance.

The refusal of most states to accept the new international law must be seen in conjunction with their refusal to take human rights seriously. Despite the plethora of human rights conventions, the enforcement of human rights protection remains weak outside Europe. States parties to human rights conventions are frequently late in their reporting. Enforcement by inter-state claims under human rights conventions is unheard of outside Europe, and even here it is rare. The International Criminal Court has not provided the deterrence that was expected: I know of no prosecution before domestic courts under the Rome Statute outside Europe, and the ICC itself is engaged in only its first prosecution. The main human rights offenders remain beyond the reach of human rights conventions or the Rome Statute and only the political organs of the United Nations may take action against them. And now there is new support for such offenders in the form of an argument raised by South Africa in the Security Council in respect of human rights violations in Myanmar and Zimbabwe. The Security Council is illegitimate by reason of its composition which means that its powers should be strictly construed. As a consequence the notion that human rights violations may constitute a threat to international peace - a notion that ironically has its origin in UN resolutions on apartheid - is no longer to be accepted! Instead all human rights issues should be referred to the Human Rights Council, where they belong. 


\section{The Human Rights Council: Different Perspectives on Palestine}

This brings me to the second section of my lecture: Human Rights and the Human Rights Council.

I was appointed as Special Rapporteur on the human rights situation in the Occupied Palestinian Territory (OPT) to the Commission on Human Rights in 2001. I now report to its successor, the Human Rights Council. I visit the region twice each year in order to prepare my reports.

The Human Rights Council, to put it mildly, has not got off to a good start. It is rightly said that it is too politicized. I share many of the criticisms of the Human Rights Council; indeed I fear it will prove to be little different from its predecessor. The main complaint is that the Council has devoted a disproportionate amount of attention to the OPT, at the expense of more pressing problems - such as Darfur and Zimbabwe.

Viewed from the perspective of the West this is true. However, viewed from the perspective of the Rest of the World (ROW), particularly Asian and African States, this emphasis is justified as the treatment of the Palestinians is, as far as the ROW is concerned, the most important human rights issue facing the world. I wish to briefly examine these different perspectives and their implications for human rights. In my view an understanding of this matter is crucial for an understanding of the actions of the Human Rights Council.

The ROW sees the OPT in much the same way as the world saw apartheid for thirty years. Like apartheid it has been before the United Nations since its inception. Like apartheid in Namibia / South West Africa, the dispute over the OPT has its roots in the League of Nations' mandate system, and the obligations of the United Nations towards a former mandated territory. Like apartheid, which sprung to world attention following the Sharpeville massacre of 1960, the issue of the OPT became more pressing in the 1960's following the six-day war of 1967. Like apartheid, there is a structural dimension: not institutionalized racism but military occupation. Like apartheid, the military occupation, coupled with settlements, resembles colonialism. Like apartheid, the OPT represents the subjugation of a developing country or people by a Westernaffiliated regime. Like apartheid, there are serious continuing violations of human rights and humanitarian law by the occupying power. Like apartheid, there are numerous resolutions of the United Nations condemning actions of Israel as contrary to international law. Unlike apartheid, however, the Security Council cannot be expected to take action on the treatment of Palestinians because of the veto of the United States, and sometimes the Western powers. This explains why the ROW has turned to the Human Rights Council. Whereas states opposed to apartheid could appeal - sometimes successfully, sometimes unsuccessfully - to the Security Council for redress, states concerned about the human rights situation in the OPT have no alternative but to appeal to the Human Rights Council.

Today I do not wish to be drawn into the question whether Israel's occupation of the OPT is similar to apartheid - a comparison which has received new attention in the West as a result of the publication of Jimmy Carter's book Palestine : Peace or Apartheid. There are clearly important differences between military occupation and institutionalized race discrimination (apartheid), but at the same time there are similarities that cannot be ignored. But this is not the point. 
The point is that the ROW expects the West to respond to the Palestinian question in the same way that it responded to apartheid - with action through the United Nations, through governments and through civil society.

The West does not see the OPT as the ROW sees it. This is reflected in the interventions and negative voting by the West in the Human Rights Council; by vetoes and abstentions in the Security Council and General Assembly; and by the de facto imposition of economic sanctions against the Palestinian people. There are a number of reasons for this, including the following: First, the West believes there are more pressing human rights issues. Secondly, the Palestinians are perceived to be on the wrong side in the war on terror. Thirdly, there is sympathy for Israel and all its actions resulting from an unarticulated awareness and understandable remorse flowing from the suffering of Jewish people at the hands of Europeans in World War II.

Failure of the West to take Palestine seriously will have serious consequences for the Human Rights Council in particular and human rights in general. The Human Rights Council will become a disaster; and the ROW will obstruct action on issues such as Darfur. The West cannot expect the ROW to take issues it regards as important seriously if it persists in its present attitude to the OPT. For the ROW the issue of Palestine has become the litmus test for human rights. If the West fails to show concern for human rights in the OPT the ROW will conclude that human rights is a tool employed by the West against regimes it dislikes and not an objective and universal instrument for the measurement of the treatment of people throughout the world.
I do not wish to underestimate the difficulties faced in searching for peace between Israel and the Palestinians. The location of the boundary between the two entities, the dismantling of settlements and the wall, the status of East Jerusalem and the right of return of Palestinian refugees remain serious obstacles to a peaceful settlement that require both understanding and compromise. These matters call for urgent attention from the West. At the same time the ongoing violation of human rights and the humanitarian disaster in the Territory cannot be brushed aside as the preoccupation of the developing world. They must be addressed.

\section{The International Court of Justice and Competing Perspectives}

I have suggested that competing perspectives threaten the future of the international protection of human rights. First, the enthusiastic promotion of the new international law by academic activists runs the risk of causing a backlash among government lawyers (and hence States) that may harm the development of international law. Secondly, the failure of the West to approach the treatment of Palestinians in a fair and evenhanded manner endangers both the Human Rights Council and the future of human rights. Happily, there is one institution that seems to have got it right - the International Court of Justice.

The International Court of Justice has approached the new international law in a cautious, balanced and principled manner. While the notion of obligation erga omnes is largely of its own making, ${ }^{9}$ the Court has dealt with it with great caution. In the East Timor case $^{10}$ the Court acknowledged that the right of selfdetermination has an erga omnes character but refused to allow this to override the principle that the court should not rule on 
the lawfulness of the conduct of a state not a party to the proceedings. In DRC $v$ Uganda ${ }^{11}$ the Court side-stepped the question of the standing of a state to protect non-nationals against human rights violations where the jurisdiction of the court is not in issue; ${ }^{12}$ a course it again followed in Bosnia v Serbia. ${ }^{13}$ Only in the Wall Advisory Opinion ${ }^{14}$ has the Court given practical effect to the concept of obligation erga omnes. ${ }^{15}$

Jus cogens - the concept of the peremptory or higher norm has been approached with even greater caution. In cases such as the Arrest Warrant ${ }^{16}$ the Court refrained from even mentioning the concept of jus cogens, despite the fact that Belgium argued that immunity could not apply where a norm of jus cogens had been violated. And where it did at last acknowledge the existence of peremptory norms in DRC $\mathrm{v}$ Rwanda, ${ }^{17}$ the court refused to allow the fact that genocide might be characterized as a norm of jus cogens to override the requirement of consent to jurisdiction.

\section{Generally, it seems that the approach of the Court is to} acknowledge the existence of the new international law, and in this way to prepare or educate states, but to apply it with great caution so as not to frighten states by confronting them with doctrines that they may as yet be unready to accept. This coincides broadly with the decision of the International Law Commission not to press for a convention on State Responsibility immediately in the light of likely state resistance to its provisions on erga omnes and jus cogens.

The Advisory Opinion of the International Court on the Wall that Israel is presently building in Palestinian Territory is significant in three notable respects. First, because it rejected the pleas of Western nations that it should refuse to give an opinion. Secondly, because it made a number of important findings on the law - that the Wall is illegal and should be dismantled; that the Fourth Geneva Convention governs Israel's responsibilities in the OPT; that settlements are unlawful; that the regimes of both human rights and international humanitarian law apply in the OPT; and that the Palestinian people have the right to self-determination. Thirdly, the court found that the obligations violated by Israel included certain obligations erga omnes with the consequence that states were under obligation not to recognize the illegal situation resulting from the construction of the wall and to ensure that Israel complied with its obligations under international humanitarian law.

It is sad that this clear and helpful advisory opinion has been ignored or abandoned by the Quartet, the body designated by the Security Council to promote a peaceful settlement in the region. No statement by the Quartet mentions the advisory opinion at all, and scant attention is paid to the wall or human rights. The Quartet, comprising the United States, the EU, the $\mathrm{UN}$ and the Russian Federation, is essentially a body of the West, led by the US and the EU. In discarding the Court's advisory opinion the West has again behaved very differently from the manner in which it behaved in respect of South Africa. The Court's advisory opinion on the Legal Consequences for States of the Continued Presence of South Africa in Namibia ${ }^{18}$ was used as an authoritative guide to states and the United Nations in their approach to South Africa's occupation of Namibia, but this has not happened in the case of the Wall opinion.

The West is understandably proud of its commitment to the Rule of Law in international affairs and disdainfully contrasts its own attitude with that of the ROW. But, again, the West's 
position on Israel / Palestine raises questions about its commitment to the Rule of Law. The resolution of legal disputes by judicial means is a major component of the Rule of Law and the referral of legal disputes to the International Court of Justice has generally featured prominently in the foreign policies of the West. It is therefore strange that, despite the wide range of legal disputes presented by the Israel / Palestine conflict, the West opposed the rendering of an advisory opinion by the Court; and once an opinion was given that provided an answer to many legal questions, the West should, through the Quartet, ignore this advice.

While an advisory opinion is not binding on states, it is surely binding on the United Nations if it approves the Opinion - as it did in General Assembly resolution ES - 10/15 of 20 July 2004, adopted by 150 votes in favour, 6 against and 10 abstentions. This makes the position of the United Nations in the Quartet untenable. As a member of the Quartet it is surely bound to ensure that this body is guided by the Opinion. But instead it is a party to Quartet decisions that simply ignore the Opinion.

The Quartet itself is an interesting body for legal consideration. While its origins are to be found in an informal decision of the Security Council - led as usual by the permanent members - it lacks any constitutional basis. It was not created by formal resolution of the Council and is largely unaccountable to the Council. Moreover, it is a party to the imposition of economic sanctions against the Palestinian people but has not followed the procedures for economic sanctions prescribed by the UN Charter. Arguably, the US, the EU and the Russian Federation are free to impose economic sanctions, but the position of the United Nations is less sure as the Charter contains prescribed procedures for the imposition of sanctions.
Questions of this kind are raised by the ROW in respect of the West's attitude towards the Israel / Palestine conflict and further explain why the ROW has chosen to use the Human Rights Council as an instrument for action. Let me repeat, I am critical of the Human Rights Council. I wish it would start addressing human rights situations in other parts of the world as well as the OPT. But I understand full well why it places the OPT at the top of its agenda and why it will continue to do so until there is progress on Palestinian statehood. And, it is clear that there can be no progress without even-handed, fair pressure on both Israel and Palestine from the West.

\section{Leiden}

Ever since my days as a law student in South Africa, Leiden has had a special meaning for me. At the University of Stellenbosch, where I studied, all my law professors had studied at Leiden. We - law students in Afrikaans - language universities in South Africa - were led to believe that Leiden ranked higher than Oxford/Cambridge or Harvard/Yale as a place of legal learning. Later, when I had come to more realistically assess Leiden's place in the legal universe, I was confronted with the genius of Grotius and the inspiration of the Grotian tradition. So I persisted, and still do persist, in my belief that Leiden is one of the greatest universities in the world, particularly in the field of international law.

Consequently it was a great honour to be appointed as Professor of International Law at Leiden in 1998. I will not deny that it was a hard decision to leave South Africa, in whose life I was deeply entrenched. I twice declined Leiden's approach and it was mainly due to Hein Schermers' persistence that I accepted. I am particularly grateful to Hein for his perseverance. When I came to Leiden I found him a good 
colleague and inspiring lawyer, one to whom I could always turn for advice and a friendly chat. I miss him.

At Leiden I found myself part of a fine tradition of international lawyers. I succeeded in a direct line to van Eysinga, Telders, van Asbeck, van Panhuys and Kooijmans. But, of course, the Leiden school of international law also embraces scholars such as van Vollenhoven, Kalshoven and Schermers. It is difficult to bring all these distinguished lawyers, with their rich intellects and diverse experiences, into one school of thought. However, I would not, I believe, be wrong in saying that they belong to the Grotian tradition - a tradition that sees international law as a system of law that serves the interests of the international community as a whole and the interests of humanity rather than the narrow interest of state sovereignty. Happily my successor, Nico Schrijver, also shares this approach to international law.

I was professor at Leiden for eight years. I cannot pretend that all my time at Leiden was happy. The "reorganization" of the Faculty was a difficult time as it resulted in the loss of two valuable members of my staff. I was also surprised that my offer to the "reorganization dean" to assist in fund-raising, based on my success in this area in South Africa, was turned down with the comment that "in the Netherlands we save money rather than raise it"!! Happily this is now past history. The Faculty is financially secure, and under the wise leadership of Carel Stolker. We have moved into a beautiful new building, which a law faculty as distinguished as that of Leiden truly deserves.

Now let me say a few words about the Grotius Centre for international legal studies. This Centre owes its creation to the work of many, but I think I can claim some credit for the original idea of such a Centre. I had, and still have, a vision of a great international law centre situated in the international law capital of the world that would become the center for international law learning in Europe. It would be a centre that accommodates all Leiden's graduate teaching, in a scholarly environment with a first-class library and adequate teaching and office space. Progress has been made with the Grotius Centre situated in beautiful premises in the Lange Voorhout. But it still falls short of the original vision: it has no real library and graduate teaching at Leiden - in the form of the advanced LLM degree - is endangered. There is clearly a case for vigorous fund-raising for the Grotius Centre and for serious attention to the future of the advanced LLM.

This brings me to the LLM degree. I was appointed at Leiden to promote the LLM degree and I saw this as my principal task. I transformed the degree from a degree which included noninternational law topics to a pure international law degree with a specialization in international criminal law. The success of the degree can, I believe, be measured by the number of Leiden graduates who today work in the international criminal tribunals in the Hague and in intergovernmental and nongovernmental organizations engaged in the practice of international law throughout the world. For me this was the happiest teaching experience of my life. I no longer had to justify the existence of international law, as I had been compelled to do in South Africa. Instead I was confronted, each year, with a diverse, bright and highly enthusiastic group of students. I hope they learned something from me. Certainly I learned much from them. Although I had a heavy teaching load, I can honestly say that I looked forward to and enjoyed every lecture. It was good to end my teaching life on such a high note. 
On the subject of the LLM, I wish to thank Thomas Skouteris and Beatrice Sicouri for all the effort they have made over the years to make a success of the programme.

It is sad that the introduction of the new BAMA degree at Leiden threatens the survival of the proper or advanced Leiden LLM degree. The decision to describe the MA component of the BAMA as an "LLM", instead of LLB (which would bring it in line with the four year LLB of most Anglo-Saxon universities) or M Juris, makes it impossible for students to distinguish clearly between the undergraduate LLM degree and the post-graduate LLM degree, now named the Advanced LLM degree. Inevitably students are opting for the cheaper and less demanding LLM degree. This has serious implications for both the Grotius Centre, whose very existence is premised on the advanced LLM degree, and the reputation of international law at Leiden. Today the reputation of a university as a school of international law depends largely on the success of its post-graduate LLM - that is an LLM for students who are already qualified in law and have had several years of experience in legal practice.

A word about $\mathrm{PhD}$ students. I have been privileged to have a number of fine PhD students with whom I have enjoyed working and from whom I have learned much. I think here particularly of Zsuzsanna Deen-Racsmany and Annemarieke Vermeer-Künzli who have probably assisted me more than I have assisted them.

I have enjoyed my years at Leiden immensely. For this I wish to thank many: Carel, Nico, Larissa, academic colleagues, administrative "medewerkers" and, above all, several generations of students.
I also wish to thank those who have organized today's seminar and valedictory lecture: Annemarieke Vermeer-Künzli, Ingrid van Heeringen and Esther Uiterweerd.

I said at the beginning of my lecture that my personal life had also changed since coming to Leiden. I married Ietje and extended my family to include a Dutch component in addition to the South African component.

Today my daughter, Jackie, represents the South African component. I wish to thank her for being with us today. I am proud that she is a human rights lawyer, concentrating on social and economic rights in the new South Africa.

Thanks, too, to my Dutch family for being here today and for having accepted me so completely.

Last, but certainly not least, my thanks go to Ietje, who has filled my life for the past seven years and will, I hope, continue to do so for many years to come. 


\section{Notes}

1 Prosper Weil "Towards Relative Normativity in International Law" (1983) 77 AJIL 413, 423.

2 Lotus Case 1927 PCIJ Reports, Series A, No 10, at p.18.

3 Asylum Case 1950 ICJ Reports 266 at 277.

4 Weil, op cit (n 1) 431.

5 Second Phase, 1966 ICJ Reports 6.

6 Article 48 of Draft Articles on Responsibility of States for Internationally Wrongful Acts, Report of the International Law Commission (2001)GAOR, 56TH session, suppl.No.10 (A/56/10)29.

7 (2006) 45 ILM 271, 376-377.

8 Dinah Shelton "Normative Hierarchy in International Law" (2006) 100 AJIL 291, 322.

9 Barcelona Traction, 1970 ICJ Reports 3,32.

101995 ICJ Reports 90, 102.

11 (2006) 45 ILM 271.

12 Ibid para 333. See, however, the separate opinion of Judge Simma, ibid, pp 376-377.

132007 ICJ Reports, para 185, 368-9.

14 Legal Consequences of the Construction of a Wall in the Occupied Territory 2004 ICJ Reports 136.

15 Paras 154-160.

162002 ICJ Reports pp 23-26. For reference to other cases in which jus cogens might have been invoked, see my separate opinion in $D R C v$ Rwanda (2006) 45 ILM 562, 609-612.

17 (2006) 45 ILM 562, para 64-78.

181971 ICJ Reports 16. 
In deze reeks verschijnen teksten van oraties en afscheidscolleges.

Meer informatie over Leidse hoogleraren:

Leidsewetenschappers.Leidenuniv.nl 


\section{PROF.DR. J. DUGARD}

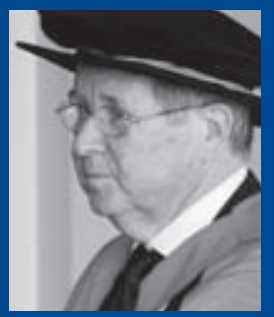

Professor Dr. John Dugard, BA, LLB (Stellenbosch), LLB, LLD (Cantab), LLD honoris causa (Natal, Cape Town, Port Elizabeth, Witwatersrand, Pretoria)

1960-1963 University of Natal, Durban

1965-1998 University of Witwatersrand, Johannesburg

1975-1977 Dean, Faculty of Law, University of Witwatersrand, Johannesburg

1978-1990 Director, Centre for Applied Legal Studies, University of Witwatersrand

1995-1996 Goodhart Professor of Legal Science, University of Cambridge

1995-1997 Director, Lauterpacht Research Centre for International Law 1998-2006 Professor of International Law, University of Leiden

2007- Extraordinary Professor of Law, Centre for Human Rights, University of Pretoria

1997- Member of International Law Commission of the United Nations

2001-2007 Special Rapporteur on the Human Rights Situations in the Occupied Palestinian Territory to the UN Human Rights Council (previously Commission for Human Rights)

2002Judge ad hoc International Court of Justice
Contemporary international law is premised on respect for human rights. I have worked to promote respect for human rights in troubled societies, such as apartheid South Africa and the Occupied Palestinian Territory, by contrasting national law with the standards of international human rights law. As a teacher of international law at the Universities of Witwatersrand, Cambridge and Leiden I have sought to make students aware of the role of international law in international affairs and the importance of seeing international law as a legal order designed not to further the interests of the State but the welfare of the individual human being. 